\title{
ANTI-AMERICANISM AND THE CLASH OF CIVILIZATIONS
}

\section{Richard Crockatt}

Among the most striking features of post-cold war debate about international politics has been the revival of talk about 'civilization' and 'civilizations'. Much of it has been stimulated by the publication of Samuel Huntington's 'clash of civilizations?' first in article form in 1993 in the influential periodical Foreign Affairs and three years later as a book. ${ }^{1}$ His argument was both simple and provocative. 'It is my hypothesis,' he wrote, 'that the fundamental source of conflict in this new world will not be primarily ideological or primarily economic. The great divisions among mankind and the dominating source of conflict will be cultural.' Nation states would continue to be important but 'the principal conflicts of global politics will occur

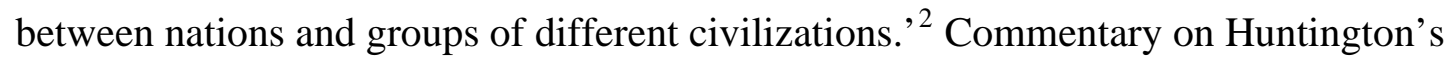
argument has reached almost biblical proportions. There are few studies of post-cold war international politics which do not address Huntington’s views, ${ }^{3}$ and discussion of his theory has extended far beyond the academy and the chattering classes. The authors of the Bush administration’s 'National Security Strategy' (September 2002), for example, felt it necessary to point out that 'the war on terrorism is not a clash of civilizations,' indicating that Huntington's formulation had become common currency. ${ }^{4}$

\footnotetext{
${ }^{1}$ Samuel P. Huntington, ‘The Clash of Civilizations?’ Foreign Affairs 72, No.3 (Summer 1993), 22-49; and The Clash of Civilizations and the Remaking of World Order, New York: Simon and Schuster, 1996.

${ }^{2}$ Huntington, 'The Clash of Civilizations,' 22.

${ }^{3}$ See the two subsequent issues of Foreign Affairs for the first bout of critiques and Huntington's response (Vol 72, Nos. 4 and 5).

${ }^{4}$ National Security Strategy of the United States of America, September 2002, 19 at http://www.whitehouse.gov/nsc/ (accessed 18/9/2003)
} 
Civilization-talk has also appeared in other guises, however, which are not related directly to the Huntington debate. Since September 11 George W. Bush has repeatedly declared that 'this [the war on terror] is the world's fight. This is civilization's fight.' 'The civilized world,' he observed in a speech to Congress on September 20 2001, ‘is rallying to America’s side.’ In his 2002 State of the Union address he declared that 'the civilized world faces unprecedented dangers' and, speaking of Iraq's weapons of mass destruction (WMD), that 'this is a regime that has something to hide from the civilized world.' In his introductory statement to the National Security Strategy, issued in September 2002, Bush noted that that 'the allies of terror are the enemies of civilization. ${ }^{5}$ This is merely a small sampling. The same rhetoric is to be found in virtually all President Bush’s major speeches since September 11.

The last time these terms had such an outing was in the first years of the cold war. Arnold Toynbee’s Civilization on Trial (1948) captured a widespread sense of being at a momentous historical turning point, and his Study of History, an abridgement of which had appeared to great acclaim the previous year, took 'civilizations' as the basic unit of study. In this he was working in a well-established grand tradition of historical theorizing going back at least to the late eighteenth century. 'Civilization' is one of those words bequeathed to us by the Enlightenment, though the idea goes back much further, having roots in any situation in which one society claimed superiority over 'savages' or 'barbarians'. ${ }^{6}$ Huntington's scheme of analysis draws heavily on

\footnotetext{
${ }^{5}$ Bush speech to Congress, 20 September 2001, http://www.msnbc.com/news/631906.asp (accessed 18/5/2002);

State of the Union Address, January 29, 2002, http://www.whitehouse.gov/news/releases/2002/01/ (accessed 25/6/03);

National Security Strategy of the United States, 1.

${ }^{6}$ See Raymond Williams, Keywords, London: Fontana, 1976, 48-50.
} 
Toynbee and one can assume that the popularity of both was due to the sense they were able to convey, in part through the language they employed, of a depth of historical perspective and weightiness of theme.

It will be clear from the above examples that there is an important distinction to be made between different usages of the terms civilization and civilized. At one end of the spectrum of meaning civilization is a neutral, scientific term indicating a certain kind of society or stage of growth which a society has reached; it is employed in the main by historians and historical sociologists as a means of categorizing various forms of social organization ${ }^{7}$. At the other end of the spectrum civilization is a highly politicised or ideological term conveying a partial and self-interested notion of what constitutes civilization. As Huntington himself observed, 'every civilization sees itself as the centre of the world and writes its history as the central drama of human history. ${ }^{8}$ To the extent that the West is dominant in today's world, there is always the suspicion among non-Westerners that the West equates 'civilization' with 'western civilization'. Such terminology in the mouth of an American president can hardly therefore be regarded as being value neutral. In between these two extremes of usage are any number of intermediate positions, but it is evidently easy for apparently valueneutral uses of the term to spill over into loaded or normative usages. The opening words of Charles and Mary Beard's seminal The Rise of American Civilization (1929) neatly encapsulates both meanings: 'The history of a civilization may, if intelligently applied, be an instrument of civilization.' Civilization is evidently, as the social scientists like to say, an 'essentially contested concept' whose meaning will always be

\footnotetext{
${ }^{7}$ A recent example is Mehdi Mozaffari, ed., Globalization and Civilizations, London: Routledge, 2002. Huntington himself explores the meanings and application of the word civilization in The Clash of Civilizations, Ch.2.

${ }^{8}$ Huntington, Clash of Civilizations, 54-55.
} 
a subject of debate and controversy, depending on who is using it and how it is being used. $^{9}$

There are several reasons for being interested in this phenomenon. My concern here is with the degree to which it indicates shifts in attitudes in America since the end of the cold war and in the way America is viewed from abroad. I am less interested in Huntington himself and the fate of his thesis than in the wider phenomenon of 'civilization-consciousness' in the United States. ${ }^{10}$ To anticipate my conclusion, I propose the following: that the international conditions of the post-cold war world in general and the post-September 11 world in particular have inclined many Americans to accentuate their 'Americanness', to enhance and even exaggerate their sense of the nation as unique and exceptional. The times have reinforced a reassertion of America's core values and a heightened sense of the nation's distinctive destiny and global role. The anti-Americanism which we see around the world is in part a response to this heightened 'civilization-consciousness' and the political and military actions which are prompted by it. Events have, in short, served to reinforce the argument Huntington put forward: that cultural conflict is a major and increasing source of global conflict.

It is not necessary, however, to follow Huntington the whole way. Indeed to accept his proposition that the conflicts we are witnessing are between civilizations is to fly in the face of the evidence that conflict is more often inside as between civilizations. But there is another necessary correction which applies as much to Huntington's

\footnotetext{
${ }^{9}$ Note debate over western civilization courses in the US. Gilbert Allerdyce, 'The Rise and Fall of the Western Civilization Course,’ .American Historical Review, 87 (June 1982), 695-725, followed by comments and author's rejoinder.

${ }^{10}$ The term is used by Samuel Huntington, see The Clash of Civilizations, 266-72, but was employed much earlier by John Dewey in his Individualism Old and New.
} 
critics as to him. Critics have questioned the equation Huntington makes between lines of cultural conflict and civilizations but few have questioned his invocation of the concept of ‘civilization’ itself. When taken together with the upsurge of civilizational rhetoric in politics and wider public discussion in the United States,

In sum, though the most obvious outcome of the crisis provoked by the terrorism of September 11 is a range of assertive political and military actions, from war in Afghanistan to the war in Iraq and beyond, there is also a significant cultural dimension to this crisis. September 11 brought it to a head but its sources lies in the structural changes consequent upon the end of the cold war. Huntington was correct to say that cultural conflict was likely to replace ideology and economics as the primary source of global conflict. The conclusions he draws from the prevalence of cultural conflict are, however, misguided and are not the only conclusions which can flow from his premise. The task here, therefore, is to rescue a cultural interpretation of global conflict both from those who have attacked it and from those who have most forcefully advocated it.

What is meant by 'civilization-consciousness'? I believe that three claims are being made by those who invoke civilization, not all of them obviously compatible. The examples I give are illustrative only and are in keeping with the exploratory nature of this paper. The first claim rests on the identification of civilization with America and is therefore an act of appropriation by America. It expresses a sense of America's distinctive identity as a nation and a culture. This is as old as America and is often 
called ‘American exceptionalism’ or ‘Americanism' or in its more strident forms '100\% Americanism.' But more than this is implied. These ideas rest on the notion that America has the capacity to be a world unto itself, that America itself constitutes a 'civilization'. Historically such notions have been as common on the left as on the right. Charles and Mary Beard's history of the United States, as we have seen, was called The Rise of American Civilization. Max Lerner's magisterial study of the United States, published in 1957, was entitled America as a Civilization. 'Like a person,' he wrote, 'a civilization is more than the sum of its parts... When you have described its people, armies, technology, economics, politics, arts, regions and cities, class and caste, mores and morals, there is something elusive left - an inner civilizational style.' In answer to the question 'Is America a civilization? He answered resoundingly yes: 'to be American is no longer to be only a nationality. It has become, along with communism and in rivalry with it, a key pattern of action and values.’ Furthermore, he concluded, ‘America represents...the naked embodiment of the most dynamic elements of modern western history., ${ }^{11}$

The argument for an American civilization as distinct from Western civilization has received a great fillip recently in the hands of the New Right in America and in particular in the context of strained relations between America and 'old' Europe. In Robert Kagan’s eyes ‘it is time to stop pretending that Europeans and Americans share a common view of the world, or even that they occupy the same world.' On major strategic and international questions 'Americans are from Mars and Europeans from Venus: They agree on little and understand each other less and less.' Nor was

\footnotetext{
${ }^{11}$ Max Lerner, America as a Civilization: Life and Thought in the United States Today, New York: Simon and Schuster, 1957, 3, 58, 61-2, 65. For a discussion of the rise of 'Americanism' in the context of a discussion of anti-Americanism see Richard Crockatt, America Embattled: September 11, AntiAmericanism and the Global Order, London: Routledge, 2003, 46-51.
} 
this a superficial or transitory phenomenon: 'when it comes to setting national priorities, determining threats, defining challenges, and fashioning and implementing foreign and defense policies, the United States and Europe have parted ways. ${ }^{, 12}$ Kagan presents an array of arguments which explain the outcome he identifies but it is worth pointing out that the notion that Europe and America were different worlds is an old one, as old as the United States itself. Indeed the perception that the old world and the new were incompatible, most forcefully presented by Tom Paine in Common Sense (1776), was what tipped the scales in favour of the argument for a declaration of independence. What is clear is that since the end of the cold war such perceptions have become prevalent on both sides of the Atlantic. Will Hutton's The World We're In makes another powerful argument, one very different from Kagan’s, for regarding America and Europe’s ‘inner civilizational styles’ as being distinct.

What these arguments come down to is the view, shared by many outsiders as well as Americans, that America is a special kind of nation, a nation of nations as Whitman termed it, granted a special destiny stemming from its uniquely fortunate situation, with claims to be a civilization on its own terms, whether or not the word itself is used. As George W. Bush put it in his 2004 State of the Union address, 'America is a nation with a mission, and that mission comes from our most basic beliefs. ${ }^{\text {,13 }}$ Civilization-consciousness at one level is thus America’s peculiar version of nationalism. It expresses claims both to uniqueness and universalism of values, the argument that America contains within itself all the world's possibilities because it contains elements of all the world's populations and because of the nature of its

\footnotetext{
${ }^{12}$ Robert Kagan, Paradise and Power: America and Europe in the new World Order, London: Atlantic Books, 2003, 1,2.

${ }^{13}$ State of the Union Address, January 20, 2004, at http://www.whitehouse.gov/news/releases/2004/01/ (accessed 22/1/2004).
} 
founding revolution which was at once unique and exemplary. This posture is at once inclusive and exclusive, outward-looking and deeply chauvinist, internationalist and nationalist. Furthermore, this stance expresses something of the effort involved in asserting an American consensus. To make a single entity of all that diversity inevitably involves doing some violence to diversity, setting some limits to difference. One would think that the United States would be well placed to deal with ethnic and cultural diversity but in fact the opposite has often proved to be the case. Precisely because it is so diverse, a premium has been placed on unifying institutions, values, and symbols, no more so than at times of national crisis such as the early years of the cold war and the terrorist attacks of September 11. The expression of those unifying elements has characterized much governmental rhetoric and policies from the passage of the Patriot Act to the key political and military moves in the war on terror. In sum, the assertion of American identity inevitably has powerful effects internally as well as externally.

The second claim implicit in 'civilization-consciousness' has to do with leadership and in particular the sense that, in all meanings of the term, America is 'bound to lead'. ${ }^{14}$ Bound in the sense that it is the natural role for a nation of America's size and power and bound in the sense that the role is forced on America whether it wants it or not. America is, from this point of view, inevitably leader of the civilized world.

This is a much more complicated issue for Americans than most non-Americans acknowledge. Outside observers of America in the last half century have often

\footnotetext{
${ }^{14}$ This is the title of a book by Joseph S. Nye, Bound to lead; The Changing Nature of American Power, New York: Basic Books, 1990.
} 
assumed that America has been determined to spread its influence and to intervene overseas wherever and whenever it had the opportunity to do so. In fact, American public opinion was and still is much more ambivalent about overseas ventures than this picture suggests. ${ }^{15}$ As leader of the 'civilized' world the United States is generally expected and expects to assume certain responsibilities and the range of economic and strategic interests has increasingly extended the net of commitments. Intervention, however, is rarely automatic, not least because of the well-documented reluctance in the post-Vietnam years of the American tax-payer to accept costly openended commitments of substantial number of American troops, to say nothing of possible casualties. Indeed this constraint was present during the Vietnam War itself, witness the stealth with which Johnson increased the number of troops and his reluctance to admit the true cost of the war to the American peoples which would have meant raising taxes and/or taking funds from his cherished Great Society programme, neither of which he was prepared to contemplate. However, the biggest constraint on large-scale overseas actions prior to 1989 was the possibility of direct confrontation with the Soviet Union or China. The deployment of several hundred thousand troops to the Gulf in 1991 and of lesser but still substantial numbers in Afghanistan and Iraq in the on-going conflict there would have been all but inconceivable during the cold war.

Some traditional constraints still exist on American interventions but the context has changed radically since 1989 and especially after the United States was the target of a direct attack on September 11. With it the issue of leadership has changed. In one sense the situation has become clearer. The United States has no rival globally,

\footnotetext{
${ }^{15}$ See, for example, Geir Lundestad's suggestion that the growth of American empire was 'by invitation' rather American design.
} 
whether one is talking about overall size of the economy, defense budgets, sophistication of weapons systems, global military reach, global economic influence and so on. ${ }^{16}$ Not that America is flawless. There are weaknesses as well as strengths in American society and the economy. There is too much domestic debt and too great a gap between rich and poor; growth areas in employment are generally in low-paid casual or temporary service jobs and deregulated capitalism has spawned corporate fraud on a massive scale. There appear also to be signs of social decay in extreme forms of crime and social violence and what one commentator has called 'the collapse of the public realm' ${ }^{17}$ In the short to medium term, however, these weaknesses do not seem likely to affect America's global position. Some of them have long been features of American life, not least levels of social violence, corruption in business, trade imbalances and so on. The basic ingredients of American power remain intact, and with the cold war enemy removed America is apparently more free to act on the global stage than at any time since the Second World War. Hence the continuing relevance of the suggestion that America is 'bound to lead'.

On the other hand, the end of the cold war complicated matters as far as American global leadership is concerned. It is not only the often-remarked absence of a clearly defined enemy so much as the absence of a ready set of rules and justifications for overseas interventions. Rather than the blanket justification of containment of communism, each intervention has to be justified on its own terms or in relation to some as yet not clearly formulated programme - Bush Sr’s 'New World Order' or

\footnotetext{
${ }^{16}$ See Paul Kennedy, 'Maintaining American Power: From Injury to Recovery,' in Strobe Talbott and Nayan Chanda, eds., The Age of Terror: America and the World After September 11, Oxford: Perseus Press, 2001, 58-60.

${ }^{17}$ See Will Hutton, The World We're In, London: Abacus, 2003 (revised edition), Chs. 5 \& 6
} 
Clinton’s 'democratic enlargement'. ${ }^{18}$ If cold war 'realism’ had supplied the necessary basis for policy choices in the period of East-West confrontation, in the more fluid world that followed the collapse of communism various elements of idealism came more to the fore. ${ }^{19}$ To put it another way, at least at the level of rhetoric the promotion of cultural values featured more prominently than before. The growth of international terrorism in the 1990s, reaching a climax on September 11 and putting the war on terror at the top of the agenda, served to enhance the cultural and idealist dimensions of policy. Since the enemy was now not a nation-state but shadowy sub- or transnational organizations, conceptions of realism apparently had limited relevance. If realism assumes a rational actor model, operating on the basis of sovereign nation-states, then clearly it could not easily encompass the new threat of terrorism. This is not to say that realism goes entirely out the window. There is not and never has been a simple either/or - realism or idealism - in the making of American foreign policy but rather various complex mixtures of the two. Crucially, a world in which terrorism was the chief threat simply did not accord with the familiar patterns of conflict and policy choices, to the extent that it was necessary to reinterpret that threat to accord more clearly with realist precepts. Hence the 'war' on terrorism and the war on Saddam Hussein's Iraq.

Furthermore, the increasing use of cultural justifications for policy choices lies in the nature of the enemy's agenda which contains a large cultural and religious element. The chances of Al Qaeda actually destroying America are slim. September 11 had numerous and complex effects but it had little actual effect on American economic,

\footnotetext{
${ }^{18}$ Richard Haass, Intervention: The Uses of American Military Force in the Post-Cold War World, Washington DC: Carnegie Endowment, 1994 usefully outlines the debates as well as providing a good deal of detail on particular interventions.

${ }^{19}$ Note the increasing invocation of and references to Woodrow Wilson among policy-makers of varying political hues. See Anthony Lake's paper etc
} 
military or political resources. The trauma of September 11 arose from the brutally unexpected nature of the attack; its effects were psychological as much as material. The challenge of terrorism is to America's conception of itself rather than to the actual fabric of its institutions, though the effects of the attacks on those directly affected can never be underestimated. It is the nature of terrorism that it seeks to and often achieves an impact far out of proportion to its physical effects and its does so by breaking all the rules of 'civilized' behaviour. One rational response to such a challenge is to reaffirm one's commitment to civilization and civilized values. More specifically, in relation to the issue in question here, the response is to assert American leadership in the fight against barbarism and on behalf of civilization.

The third claim implicit in 'civilization consciousness' in some ways runs counter to the first two. Though I treat it last, it is perhaps the most obvious application of the term. It relates to the identification of the United States with the 'civilized world' which is larger than the United States physically and more extensive culturally. Traditionally the identification has been with Western Civilization. Rarely in the contemporary world is it restricted to the 'West' since the United States takes pains to include under the rubric of 'civilized' all those nations and cultures which are willing to join the United States in the war against terror, wherever they are geographically and whatever their religion or culture. That includes Muslims who reject the attempt of bin Laden and others to identify their cause as that of Islam as a whole. America's fight, it has been reiterated by members of the American administration from Bush downwards, is not with Islam but with extremists who have hijacked Islam for their own murderous purposes. For its part, the American Muslim community has declared 
its allegiance to the United States. The American Council For Islamic Affairs, along with other Islamic bodies in the United States, has taken pains to dissociate itself from 'Islamic terrorism’ and to stress the Americanness of American Muslims. ${ }^{20}$

The most obvious manifestation of this aspect of civilization-consciousness lies in the effort to build a coalition against terror and more broadly to associate that effort with the defense of civilization. It is presented as a collective effort, admittedly led by the United States but operating on behalf of the larger whole, indeed the largest possible whole which includes all those who lay claim to the term 'civilization.' Inclusivity is the goal here with the aim of drawing the clearest possible line between friends and enemies, a line which invokes social and ethical as well as political values.

It would seem that the first and third claims of civilization-consciousness are at odds with each other. In the first aspect the invocation of civilization is an act of national appropriation which lays down a challenge to potential friends and enemies of the United States alike. Can you measure up to our values? Will you support our fight? In the third claim the emphasis lies on collective, cooperative values and is more a matter of the United States reaching out to like-minded nations, drawing the net wide, accentuating supposedly commonly held values. This might be regarded as a contradiction. How can a nation or a culture be both unique and representative of universal values? The answer could be that however contradictory these claims might appear in theory, they are resolved by means of the second claim: in the practice of

\footnotetext{
${ }^{20}$ For an early example of the Bush administration's insistence that the war against terror is not a war against Islam see Bush's speech on 20 September 2001. For a perspective on the experience of American Muslims since September 11 see Muqtedar Khan, 'Putting the American in "American Muslim”' New York Times September 7, 2003. For a discussion of Islamic-American relations since September 11 see Richard Crockatt, 'No Common Ground? Islam, The United States and AntiAmericanism,’ European Journal of American Culture, forthcoming 2004.
} 
American leadership. There is in practice no fundamental contradiction between the assertion of American nationalism in the name of civilization and the invocation of a world community in the name of civilization. In short, claim number one represents the American argument for the uniqueness of its culture - its ‘civilization'; claim three expresses the American argument for the universalism of its values, while claim two is the bridge between them. It is the means by which claim one can give reality to claim three. They are both strategies which rest on the overwhelming given of American dominance and American leadership. Which strategy is employed at any particular time depends on the needs of the moment.

I shall conclude this section by drawing attention to a document which links all three aspects and also illustrates some of the political and other difficulties raised by such emphatic and naked assertion of cultural values. I refer to the September 2002 National Security Strategy, which does for the war on terror what National Security Document 68 (NSC-68, 1950) did for the cold war: sets out the political, military and ideological basis for an overall strategy. NSC-68 was, of course, an in-house document, not made public until a quarter of a century later. The 2002 National Security Strategy was a very public document, designed to enlist public support for the war on terror. NSC-68, however, was no dry-as-dust position paper but a powerfully rhetorical and ideological effort designed no less than the 2002 strategy to persuade, except that in the case of NSC-68 the audience was government rather than the people. Significantly, there are close parallels in rhetoric and content between the two documents, not least the conclusion reached in both cases that a transformation of military doctrine was necessary to fight a worsening global threat. 
The 2002 National Security Strategy is famous for spelling out the doctrine of preemption. I am concerned here not with that doctrine, important though it is, but with the rhetoric of freedom with which the document is peppered. In itself this is nothing new in American history and foreign policy; it is perhaps America's core value and is regarded as the basis on which all other values are founded. What is particularly significant is firstly, the context of war followed by nation-building in Afghanistan followed by the same in Iraq and secondly, the association of this value with what is called the 'non-negotiable demand of human dignity'. Claims are made here on behalf of America's own history and values, on behalf of American leadership in the current crisis and on behalf of the civilized world whose values are taken to be at one with those of the United States. Crucially it is being claimed that these things are all essentially coterminus. American universalism has rarely been more plainly or more comprehensively expressed; to find comparable claims one has perhaps to go back to Woodrow Wilson, though his are in a somewhat different key. Crucially, America's core demand is 'non-negotiable'. This is doubtless intended in a benign sense to convey the deep, self-evident nature of the value of human dignity - self-evidence being central theme of American discussion of values from the Declaration of Independence onwards -- but it conveys also a questionable assumption about the applicability of America’s interpretation of 'freedom' and 'human dignity’ to other nations and situations; it betrays indeed a potentially coercive and illiberal insistence that America's values are or should be those of all nations. The issue is not whether one believes in freedom - freedom is like food in that you can't be against food -- but what freedom means in different cultures. (We don't all need to eat the same food.) The formulation in this document scarcely leaves open the possibility of debate about 
what freedom means to different peoples. Much of what we call anti-Americanism is a reaction to the sorts of assertions contained in this document. To this we now turn.

Anti-Americanism is one consequence of the growth of America's civilizationconsciousness. Having said that, it is necessary to point out that 'anti-Americanism', like all the terms involved in this discussion, refers to a complex of attitudes and admits of many definitions and explanations. Indeed the term itself is highly political, employed as it often is as a label for attitudes that the user dislikes rather than as a neutral analytical term. Like 'civilization', it is an essentially contested concept. Not least of the difficulties involved is where to draw the line between anti-Americanism and legitimate or rational criticism of American policies. Such decisions are inevitably based on political presuppositions rather than widely agreed canons of evidence. Anti-Americanism is a complex of attitudes towards the United States whose sources are varied according to the nature of the relationship of particular nations, cultures and individuals with the United States.

What cannot be denied, however, is that public consciousness of negative attitudes towards the United States has been powerfully stimulated by the events of September 11 and after. Americans and others want to know 'why people hate America'. It is the disposition to label as much as the meaning of the label which demands explanation. Thus for the purposes of discussion we shall use an element of short-hand, defining anti-Americanism firstly as a predisposition to doubt whether the United States power can ever be used for good and secondly, a distaste for the way in which America goes 
about expressing its will and asserting its power. Anti-Americanism thus represents a reaction to the exertion of American power and also to the expression of American culture. I am concentrating on the latter here but clearly it is because American power is so great that the nature of its culture matters to so many others. Indeed separating the two is virtually impossible.

Anti-Americanism has often attached itself to such apparently trivial matters as the way in which President Bush expresses himself, in particular the (to many nonAmerican eyes) incongruously folksy terms in which he discusses the search for bin Laden and other terrorists. 'We'll smoke'em out, 'keep those folks on the run' etc. Behind the reaction to such language in many of the older nations of Europe lie two centuries or more of denigration of American democratic culture combined with growing resentment of American power. ${ }^{21}$ The result is that curious amalgam of superiority and inferiority complexes which often characterizes the old world's perception of the new. The American reaction to September 11 in all its political, military, and cultural ramifications has reminded us how different America is from other cultures. The political complexion of the Bush administration has undoubtedly served to intensify this perception. The American right - and this is arguably the most consistently right-wing administration in post-World War II history - is generally more nakedly patriotic, more nationalist in complexion, more emphatic in its assertion of traditional American values (especially those associated with the founding period) than Democratic administrations. Policy seems to be forged in the American heartland where 'real' Americans live rather than among the more sophisticated ‘European’ east coast elites. (Shades of Chambers v Hiss, McCarthy v Acheson etc) I say 'seems’

\footnotetext{
${ }^{21}$ See Crockatt, America Embattled, ch.2 'How the World Sees America: The Roots of AntiAmericanism'.
} 
because in fact the main figures in the neo-conservative camp are east coast intellectuals. There has justifiably been extensive media and academic commentary on the agenda of the new Right and its influence on the Bush administration.

We shall look at reactions to the three aspects of civilization-consciousness in turn, though inevitably there is will be some overlap in the treatment. It is easy to see why those who are already firmly opposed to America will react strongly against America's post-9/11 assertiveness. More significant perhaps are the reactions of those who have no automatic opposition to America but who find themselves embattled in the new climate of the war on terror. The problem here is not simple hatred of the United States but the difficulty of living with a United States which makes such grandiose claims on behalf of its own 'civilization'. This applies, for example, to many in the Muslim world, including American Muslims, who fear that the cost of total identification with the war against terror will be the dilution or even suppression of their own national, religious or cultural identity. Even gestures of friendship by members of the American administration towards Muslims may be regarded with suspicion by Muslims. Such anxieties predate the attacks of September 11. One Muslim observer noted that the Clinton administration tended to divide Islam into two polarized camps: at one end were the extremists who advocated a militantly 'political Islam' and were regarded as terrorists or supporters of terrorism; at the other end of the spectrum was 'Islam' itself 'represented by the faith that is confined to personal belief and ritual practices.' But while apparently affirming respect for Islam, this latter version of the religion was 'a disembowelled Islam that has no input into the human, social, economic and political values, which some Islamists have dubbed "American 
Islam.”, 22 As many Muslims see it, the price of friendship with America, or for citizenship of the United States, is denial of the full expression of Islam. To put it another way, American civilization does not appear to have a place for Islam.

Under Bush, and especially since September 11, the dilemma for American Muslims, indeed Muslims everywhere, has deepened. Despite efforts to insist that the war against terror is not a war against Islam, despite speedy correction of some earlier faux pas in the war against terror such as terming it a 'crusade', and despite efforts by members of the Bush administration -- among them Condoleeza Rice - to reach out directly to the Muslim community, scepticism about the administration's attitude to Muslims remains. The passage of the Patriot Act, with its threat to Constitutional rights, is one source of concern, as is the general climate of suspicion of individuals with a Middle Eastern connections or even look.

In this connection America's deep military and political entanglements in the Middle East complicate matters for Muslims in America and elsewhere. Failure to make progress on a settlement of the Palestinian-Israeli conflict is doubly damaging: damaging to the parties directly involved and damaging to Muslims everywhere who suspect that the American administration's failure to push more strongly for a settlement reflects its true estimation of the significance of the Palestinian issue for them and also tends to reinforce the association of Islam with terrorism. As long as the news about Islam is mainly about terrorist incidents, the deeper will the general suspicion be of Islam and the more vulnerable will individual Muslims be. If such scepticism and anxiety is present among Muslims who are basically sympathetic to

\footnotetext{
${ }^{22}$ Yvonne Yazbeck Haddad, 'Islamist Perceptions of US Policy in the Middle East,' in David W. Lesch, ed., The Middle East and the United States: A Historical and Political Reassessment, Cambridge, MA: Westview Press, third edition 2003, 481.
} 
America and who deplore Al Qaida et al as perverters of the Muslim faith, how much more alienated will be those Muslims who have no natural sympathy with the United States and regard it simply as an agent of imperialism?

Similar issues apply pari passu to Europe which in the post-cold war world has gained new perception of the differences between European and American ‘civilizations'. (The same applies, of course, in reverse.) Cultural differences, needless to say, have been part of the long history of European-American relations, and anti-Americanism is part of that history. The collapse of the cold war, however, has allowed for fuller expression of such sentiments because the tight geopolitical tie promoted by the cold war no longer underpins the relationship. There is more fluidity, less obvious need for coordinated policies especially on defence, more scope for conflict in the relationship, and more opportunities for cultural differences to find expression. American unilateralism provides a target for these concerns just as it expresses America’s own cultural and political imperatives.

If anti-American feeling attaches itself to heightened expressions of Americanness, it attaches also to America’s leadership role; indeed the two areas are obviously closely linked. The awareness that the war on terror is to be fought on America's terms, that America defines these terms, that America supplies the bulk of troops and means to fight the war, and dictates the strategy promotes resentment even among those who share the goals of the United States. The best that can be hoped for among those who wish to influence the way the war on terror is fought - and this is seemingly the basis of Tony Blair's strategy - is to adopt America's goals as their own in the hope that they may be able to influence the direction and pace of American policy. This is not 
to say that Tony Blair has been insincere in his support of President Bush, not even that he may not have succeeded to some degree in his aim, but it is to say that he has had to go further in Americanizing his approach than normal alliance politics would seem to dictate. To an unusual degree, which is not to my knowledge matched in the cold war years, with the possible exception of the Thatcher/Reagan axis, Blair has adopted the American reading of global events and more to the point has adopted an American style of international politicking, including an unusual level of rhetorical inflation. $^{23}$

It seems clear that the dissociation of countries such as France, Germany, and Russia from the American way of fighting the war on terror has partly to do with style. One cost of support for the United States political goals is a degree of subordination to the style in which they are couched. Evidently resistance on the part of many Europeans has to do with a lot more than style but no one who watched the debates in the UN Security Council on the proposed second resolution on Iraq could be in doubt that Colin Powell and Dominic de Villepin were speaking different languages, and I don't mean only that Powell was speaking English and de Villepin French. They were expressing different cultures, voicing different assumptions. They started from different places. Such exchanges were eloquent testimony to the fact that American leadership of the war against terror was both inevitable - in the sense that it could not be resisted -- and problematic. From the American point of view (which is shared by Tony Blair) the idea that a strong Europe should act as a counter-balance to US power is tantamount to obstructionism. Indeed there seems to be no place in the American scheme of things for that old realist nostrum: the balance of power.

\footnotetext{
${ }^{23}$ See Crockatt, America Embattled, 149.
} 
Finally, Anti-Americanism attaches also to the third aspect of civilizationconsciousness: the effort to enlist all nations in an enterprise which transcends the scope and interests of any one nation, that enterprise being civilization itself. At one level there is resistance to the idea that the United States truly represents the ideals of civilization which it claims to uphold. Treatment of the prisoners at Guantanamo Bay is the most commonly cited issue here. Secondly, there is the belief on the part of critics that the fight for 'civilization' is loaded towards America's interests and that it is no more nor less than a fight for America’s national interest dressed up to look like a cooperative venture. The 'coalition of the willing' from this point of view is really a coalition of power based on America's ability to exert pressure on other nations. American tactics at the UN during the build-up to the war in Iraq were, from this standpoint, the perfect illustration of special pleading, arousing the suspicion among sceptics that America had already made up its mind about Iraq and was merely going through the motions. Once this conviction was established in the minds of unsympathetic observers, it could only become further entrenched as the rhetoric became further inflated. The more insistent was the President on the necessity for war to defend civilization the greater the scepticism with which these claims were regarded. Anti-Americanism, to the extent that attitudes went beyond criticism of policy [if this line can be drawn], fed on a sense of the gap between the nature of the claims being made on behalf of war and the actual motives which were conceived to be the advancement of American interests, whether for oil, a dominant role in the Middle East, etc. In short, it was easy to doubt whether the United States could really claim to speak on behalf of global 'civilization'. 
Huntington's clash of civilizations thesis has been the target of some justified

criticisms. What he called civilizations are not the discrete entities he imagined. True, he allows for various forms of conflict within civilizations and countries but the larger thesis would fall if he were to allow intra-civilizational cleavages to predominate over those between civilizations. But the fact is that in the age of globalization the boundaries between nations and cultures are increasingly porous and, as many of Huntington's critics have pointed out, there are as many clashes inside civilizations as between them. There is thus a real problem with his use of civilization as his main unit of historical study.

Huntington was not wrong, however, to see cultural, especially religious and ethnic, conflict as having increased saliency in the post-cold war world. In many parts of the world where cold war pressures had reduced these to a state of suspended animation, the end of the cold war gave them new life. The task, then, is to adapt Huntington's ideas and make them work for us. If he has done a service, it is to expose the degree to which ethnocentrism can be a source of conflict. He has reminded us that, as Robert Cooper has put it recently, 'foreign policy is not only about interests.' 'At moments of crisis,' Cooper continues, 'it is likely that a nation will return to its roots and its myths and respond as the heart urges rather than as the head advises. ${ }^{24}$ The danger is of failing to perceive that this applies to ourselves and not just our adversaries. In Huntington's analysis it is generally other cultures' assertiveness which is the problem, not least Islam which is said to have 'bloody borders'. Huntington takes less account of how other nations and cultures might regard

\footnotetext{
${ }^{24}$ Robert Cooper, The Breaking of Nations: Order and Chaos in the Twenty-First Century, London: Atlantic Books, 2003, 127, 136.
} 
America's way of acting in the world and in this he reflects the larger problem of ethnocentrism in the American policy-making process. The greatest challenge, I believe, in this more fluid, globalizing world is for nations to develop awareness of how their actions and belief systems impinge on others. For America, because it is so powerful, this means being conscious of the power of culture as well as the culture of power.

There is a second limitation in Huntington's thesis which also gives rise to a challenge. His analysis assumes that cultural difference tends always to produce conflict. In response I would say that it may do but need not. If you assume that cultural difference will always give rise to conflict, then it is very likely that it will. The challenge is to develop ways of cooperation between cultures and nations which mean different things by words which appear to have self-evident meanings: freedom, democracy, human rights, justice. Rather than assume that we know exactly what these things mean and dismiss those who interpret them differently, it may be prudent to develop dialogues. At least this may open the possibility of isolating those for whom difference will always and only imply conflict. 